\title{
Diversity in the standard of living among populations in European post-comunist
} countries

\author{
Tomasz Michalski
}

Department of Regional Development Geography, Faculty of Oceanography and Geography, University of Gdańsk, Bażyńskiego Str. 4, 80-952 Gdańsk, Poland

E-mail address: michalski.tomasz@ug.edu.pl

\begin{abstract}
The aim of this study was to present the general situation of populations of European post-communist countries 25 years after the collapse of communism in Europe. The study consists of two parts. The first one briefly discusses the processes that led to a significant diversification in the social, economic and political situations of the populations of the studied countries. In the second part the diversity of this situation is shown (using: the Legatum Prosperity Index, the Social Progress Index, and the Human Development Index). It was found that the best situations exist in the countries which quickly and effectively implemented reforms, and whether they were independent states, or parts of larger states, under communism is of secondary importance. It is symptomatic that these are countries situated in the north-western part of the area under consideration, which corresponds to the current situation in the EU-15, where the countries located in the south (the so-called PIGS) have poor economic and partly social situations than those in the north. Furthermore, it was found that the situation with the population of Russia is worse than in many countries which were previously under the occupation of the USSR or were dependent on the authorities in Moscow.
\end{abstract}

KEY WORDS: Central Europe, Eastern Europe, standard of living of the population

\section{Introduction}

The objective of the study was to present the social, economic and political situations of societies of European post-communist countries 25 years after the collapse of communism in Europe. The emergence of the first non-communist government in Poland in 1989 triggered the dismantling of the system in Europe. As a result of various directions and the intensity of transformation processes, societies of the former European communist countries are currently at very different levels of civilization development, prosperity, respect for civil liberties, etc. The group of European postcommunist states included: (1) the former European Union republics of the former Union of Soviet Socialist Republics (USSR) plus Russia; (2) the countries of the former Yugoslavia, and Albania; (3) the former European countries of the socalled people's democracy (without the former
German Democratic Republic, which is now part of united Germany).

The study consisted of two parts. The first one generally shows the most important processes that brought about changes in the analysed group of countries, while in the second part an assessment of the standard of living of the citizens of these countries for the year 2014 was made with the use of three indicators: the Legatum Prosperity Index, the Social Progress Index, and the Human Development Index. The breakdown of these countries into groups was based on the methodology of Hellwig's critical gap (HELLWIG, 1968).

The Legatum Prosperity Index is an indicator of a destimulant nature. It is calculated on the basis of variables (a total of 89) grouped into 8 categories: Economy, Entrepreneurship \& Opportunity, Governance, Education, Health, Safety \& Security, Personal Freedom, and Social Capital. These variables are weighted, and on this 
basis the ranking of the country is determined. The index is developed by the Legatum Institute (http://www.prosperity.com/\#!/).

The Social Progress Index is an indicator of a stimulant nature. It contains 52 variables that are divided into three groups (Basic Human Needs, Foundations of Wellbeing, and Opportunity) within which 12 subgroups are distinguished. It is developed by an organization called the Social Progress Imperative (www.socialprogressimperative.org/).

The Human Development Index is also an indicator of a stimulant nature. It assesses three aspects in particular countries: a long and healthy life, knowledge, and the standard of living. The index is developed by the United Nations Development Programme (http://hdr.undp.org/en).

\section{The complexity of the transformation processes}

After 1989, the direction, course and intensity of the transformation processes were very different in the analysed group of countries (cf. SOBCZYŃSKI, 2010, 2013). For the sake of argument, these processes can be divided into those of a more internal dimension and the more trans-national ones.

Internal (domestic) changes have been considered as more important ones. They can be divided into those taking place in the political, economic and social sphere.

The most important changes taking place in the socio-political realm included the changes of the political and legal systems, and regaining control over the army. In all European postcommunist countries soon after abolishing the system, amendments to the law on the principles of the functioning of political parties and elections were made. The characteristic feature of systemic changes in the countries of the region was to move away from a centralized communist state based on a one-party model, or a quasi-one-party one towards a model based on the principles of the democratic rule of law (JASKIERNIA, 2002).

Simply put, the analysed countries can be divided into two groups: (1) those in which postcommunists took over power, and (2) those in which governments were formed from former dissidents. This division was especially important at the beginning of the analysis period, when the fate of economic reforms was at stake. Countries in which the opposition took power quickly initiated major reforms that resulted in a short-lived deep crisis, followed by a period of rapid development. However, in the case of countries where postcommunists came to power a continuous deterioration of their economic situation took place. In the extreme form of the latter case, postcommunists initiated wars (the former Yugoslavia), which plunged the countries into even further chaos.

Judiciary reform played an important role in the process of transformation of post-communist countries. In the communist period, judicial independence was frequently illusory and often at the service of the ruling Communist Party. Hence, much space in the reform of law was devoted to the independence of courts. Yet in some countries there was a significant alienation of certain rules of law in relation to actual reality. This can be clearly seen in the Ukraine throughout the whole period since gaining independence, where "there is legal nihilism, ranging from higher levels of authority to citizens" (LESEČKO \& ČEMERIS, 2001, p. 95). Values of the Corruption Perception Index can be a good example of the diversity of the situation in this respect, in 2014 it was in the range $^{1}$ of 69 for Estonia and 61 for Poland to just 27 for Russia and 26 for the Ukraine.

It was characteristic of the analysed countries that the armed forces were sub-ordinated to Communist parties, and the Soviet/Russian army was present. Hence, it was so important in the early years to limit the influence of communists in the armed forces. This was done the fastest (already in 1989) in Poland, Czechoslovakia and Hungary. The situation in the countries that previously belonged to the former USSR was very complicated; the Soviet army was stationed inside each of them, and their citizens conscripted to that army were scattered around the Warsaw Pact (cf. SOBCZYŃSKI, 2002). Ukraine's efforts to gain control over the Black Sea Fleet should be considered a spectacular failure, which would later backfire during the invasion of "little green men" linked to the authorities in Moscow. On a spatially smaller scale, the same problem occurred with Yugoslavian/Serbian troops.

At the time of regaining actual independence, the former communist countries facing the need to reform their economies were in a doubly disadvantaged situation. On the one hand, they had to transform themselves to convert the previously existing centrally controlled economy. This created a need to address, among other things, massive corruption, high inflation or a necessity to carry out privatization processes (BĄK, 2006; KARKLINS, 2009; KoŁODKO ET AL., 1991; SŁOBODZIAN, 2010). On the other hand, they had to deal with the process of globalization and the associated

1 The higher the value, the better the situation. 
post-modern changes in their economies (KoŁODKO, 2001).

An additional problem in the former communist countries was the break in their existing economic relationships (STRYJAKIEWICZ, 2004). This process mostly affected those countries arising out of the rubble of Yugoslavia and the Soviet Union.

Also the legislation and corrupt practices in some of the countries analysed were not conducive to economic freedom (HoLMES, 2009; KARKLINS, 2009). The Index of Economic Freedom was 75.9 for Estonia and 73.0 for Lithuania, for Belarus it was just 50.1 and 49.3 for the Ukraine in 2014.

During the period of communist enslavement, a new kind of man came into existence, called homo sovieticus by TISCHNER (2005) and ZINOVIEV (1986). He was especially "visible" in those societies that were under the control of Moscow since the October Revolution. For example, according to WìnNìKOW \& MOROZOWA (1998), despite their declared pro-democratic orientation, Ukrainians were, however, deeply related to the totalitarian type of political system, which significantly slowed down the process of democratization and proper reforms.

Transformations in the social sphere can be viewed from an individual and a group perspective. In the first case, alongside a number of positive phenomena, a negative one appeared - the trauma of post-communism, as SZTOMPKA (2000) called it. However, in terms of the group perspective this is primarily the emergence of civil society. WENDT (2007) distinguishes internal and external factors affecting its formation and transformation. The internal factors are political (such as changing the political system and creating units of territorial self-government), economic (restructuring the economy and introducing a market economy), and social (the appearance of unemployment, developing new citizenship attitudes, developing non-governmental organizations or the shaping of the middle classes). By contrast, external factors are again political (some countries' accession or declared willingness to become part of the European Union and the North Atlantic Treaty Organisation), economic (changes in the world economy and diffusion of innovation) and social (impact of mass media, ease of communication, impact of global culture and, finally, adopting pro-social attitudes). Yet, the progress of these processes in the various countries of the region is very diverse. For example, the World Press Freedom Index in Estonia amounted to ${ }^{2} 9.63$ in 2014, while in Russia it was 42.75 and in Belarus 47.82.

\footnotetext{
2 The lower the value, the better the situation.
}

Local governments also had an important role in shaping civil society. In the communist period its capacity was fictional but after regaining independence laws relating to giving it real powers were adopted. In addition, reform of the administrative division had already been implemented in some of the countries. However, the complete empowerment of local government has encountered various obstacles. Moreover, in some of the countries analysed (e.g. Ukraine) there is a lack of specific mechanisms for implementing democracy, which is a result of a lack of understanding of the nature of self-government both at local and central levels (KUČABS'KIJ, 2009). Another problem is the need for local authorities to find themselves a new role - not as administrators but as managers of the region at a local level.

On the other hand, one can see some positive aspects of the impact of homo sovieticus on the population's situation, especially on women. The Gender Development Index has some of the highest values $^{3}$ in post-Soviet countries: Estonia (1.042), Russia (1.038), Lithuania (1.036), Latvia (1.033), Belarus (1.021) and Ukraine (1.012).

In comparison to the processes of a domestic character, those with international overtones were considered secondary. Five processes of a trans-national character have been distinguished after 1989 in the area analysed:

1. The dissolution of union states: the USSR, Czechoslovakia and Yugoslavia with a simultaneous reunification of Germany. There is no certainty whether this process has finished or whether we will face further disintegration of countries. On the one hand, this is a grassroots process, as the emergence of Kosovo, for example; but on the other hand, the neoimperialist politics of Russia (as explained in the following point) has a big influence.

2. A relatively quick liquidation of international organisations, which were the control tools of the former Soviet Union over the former satellite states. In 1991, both the Warsaw Pact was dissolved (then Bulgaria, Czechoslovakia, Hungary, Romania, Poland, the USSR ceased being its members; while Albania left earlier in 1968, and the GDR in 1990) and the Council for Mutual Economic Assistance (then Albania ${ }^{4}$, Bulgaria, Czechoslovakia, Hungary, Romania, Poland, the USSR ceased being members, and Yugoslavia its associated member; and the GDR in 1990).

3 The higher the value, the better the situation.

4 Since 1962 it stopped taking part in works of this organisation, still formally not ceasing to be its member. 
3. A multi-step process of the already sovereign countries joining the North Atlantic Treaty Organisation (in 1990: the GDR as part of Germany; in 1999: the Czech Republic, Poland, Hungary; in 2004: Bulgaria, Estonia, Lithuania, Latvia, Romania, Slovakia, Slovenia; in 2009: Albania, Croatia) and the European Union (in 1990: the GDR as part of Germany; in 2004: the Czech Republic, Estonia, Lithuania, Latvia, Poland, Slovakia, Slovenia, Hungary, in 2007: Bulgaria, Romania; in 2013: Croatia; as of 2015, Albania, Montenegro, Macedonia, Serbia remain official candidates).

4. The formation of grass-roots regional integration groups. There is a whole host of them, and the most important ones in the period of transition included: the Visegrad Group (whose greatest achievement was the appearance of the Central European Free Trade Agreement in 1992), the Central European Initiative, the Council of the Baltic Sea States, the Baltic Assembly, Organisation for Economic Cooperation BSEC, GUUAM.

5. Efforts to rescue the former imperial position of Russia in the region, this time based on nationalism (see GREGOR, 1998; INGRAM, 2001; ŁATKOWSKI, 2001). These have intensified since Putin's take-over of political power in 2000 . The current Russian political elite, represented by V. Putin and his entourage, derive from the old Soviet elite. They abandoned communist demands, while still preserving the vision of Russia as a world power (JILGE, 2014; MoskWA, 2013; RUTLAND, 2012). Adopting the assumptions derived from the days of the USSR about impact zones - the Russian Federation seeks to, inter alia, rebuild its dominance even in areas of the so-called near abroad. Since the beginning these actions are multi-faceted in nature and are related to: (1) politicalphilosophical activities that justify the special position of Russia (e.g. the promotion of the concept of the so-called "Russian world" (Русский мир: http://russkiymir.ru/) or an expansion of the network of Orthodox parishes that remain in a hierarchical relationship with the Patriarch of Moscow; (2) activities in the economic-political field, as for example the establishment of the Commonwealth of Independent States in 1991 (from the countries analysed these include: Belarus, Moldova, Russia, Ukraine ${ }^{5}$ ) and creating the Union State of Russia and Belarus in 2000 on the basis of prior agreements (the oldest dating from 1996), of gas wars with Ukraine, for example in 2006, 2008 and 2014; (3) activities in the politicalmilitary field, whose most obvious examples are the emergence of a network of pseudostates connected to Moscow (Abkhazia, South Ossetia, Transnistria), supporting Armenia in the conflict of Nagorno-Karabakh, and in particular the annexation of Sevastopol and the Autonomous Republic of Crimea and the direct military support of separatists in the war with Ukraine in the Donetsk and Luhansk oblasts.

Together, these two groups of processes have led to a significant diversification in the situation of the populations in the area under consideration.

\section{Diversification in the standard of living of the population}

The positions $\mathrm{s}$ of the countries analysed in this classification was based on the Legatum Prosperity Index in 2014 and ranged from 91 position for Bosnia and Herzegovina to $24^{\text {th }}$ for Slovenia (Kosovo was excluded due to a lack of data). The countries analysed have been divided into four groups (Fig. 1). The best situation was in the states that early and consequently implemented reforms plus Bulgaria and Belarus. Symptomatically, there is no clear division here into post-Soviet, post-Yugoslavian and other post-communist countries. If a high position, and hence good living conditions, in countries that have successfully carried out transformation processes ${ }^{6}$ is understandable, then it is difficult to understand the good position of Bulgaria and Belarus. Although now Bulgaria is also a member of NATO and the EU, its first years of the transition process proceeded badly (ILIEVA \& MiCHALSKI, 2001), due amongst other things to the fact that postcommunists were in power. However, in the case of Belarus, where the authoritarian government of A. Lukashenko is still in power (cf. CZERWIŃSKI, 2005), one can most likely talk about "patching" statistics. The second group, which can be called a middle one, is quite diverse, because on the one hand, there is authoritarian Russia, and on the other hand Ukraine with its oligarchic system, and with Romania and Macedonia with poorly implemented reforms and Montenegro quickly trying to catch up. The worst situation occurs in two groups of countries: in Serbia enfeebled by war and lacking a clear vision for its development and in Albania, Bosnia and Herzegovina, and the Republic of Moldova torn by conflicts. 


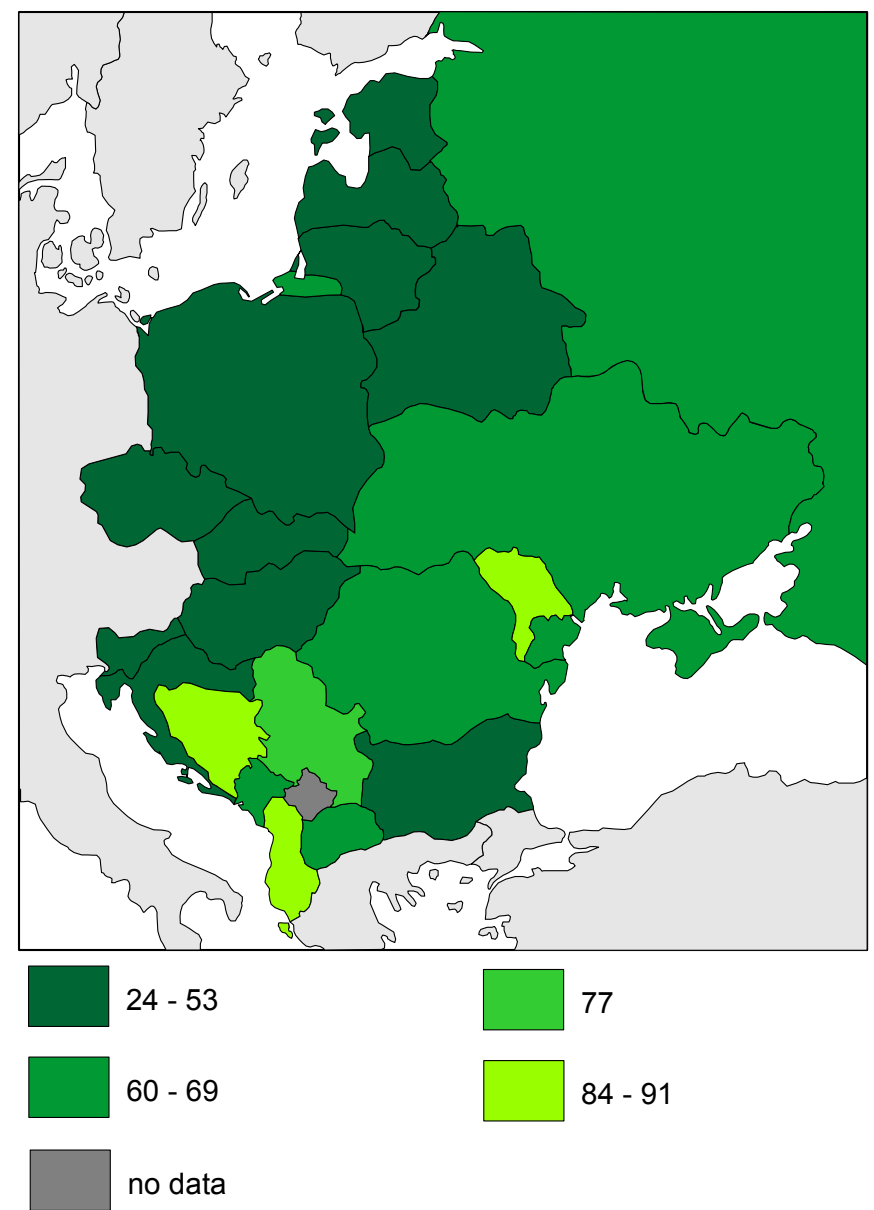

Fig. 1. Location of European post-Communist countries according to the Legatum Prosperity Index in 2014 (source: http://www.prosperity.com/\#!/)

On the basis of the Social Progress Index for 2014, the best situation was observed for the population of Slovenia, and the worst was for Moldova (Kosovo was excluded due to a lack of data). The countries analysed were divided into four groups (Fig. 2). The best situation was reported for those countries committed to undertaking reforms since the very beginning: the Czech Republic, Estonia, Poland, Slovakia, and Slovenia. A little surprising is the absence of Hungary in this list. The second group mostly consists of countries that have also carried out reforms with significant commitment: Croatia, Latvia, Lithuania, and Hungary. The third group is very diverse. Symptomatically, apart from post-Soviet Belarus and the Ukraine, these other countries are located in the south of the study area. Comparisons with the current economic and social situation amongst the countries of the "old" European Union are quite natural at this point. The worst situations were reported in Russia and Moldova.
Data on the value of the Human Development Index were available for 2013. The best situations were reported in Slovenia, the worst in Moldova (Kosovo was excluded due to a lack of data). The examined countries have been divided into five groups (Fig. 3). The first two groups include countries with a very good (the Czech Republic and Slovenia) and a good position (Croatia, Estonia, Lithuania, Latvia, Poland, Slovakia and Hungary). Similar to the previous classifications, one can conclude here that these are all countries which quickly and effectively carried out the process of transformation. The third group, of a transitional character, includes very different countries, with, on the one hand, Bulgaria, Montenegro and Romania which have implemented reforms (albeit less successfully); and on the other hand, autocratic Belarus and Russia with hindered reforms. The fourth and the fifth groups include countries with the worst situations. These are countries in which there was or still is no clear vision for the direction of reforms. 


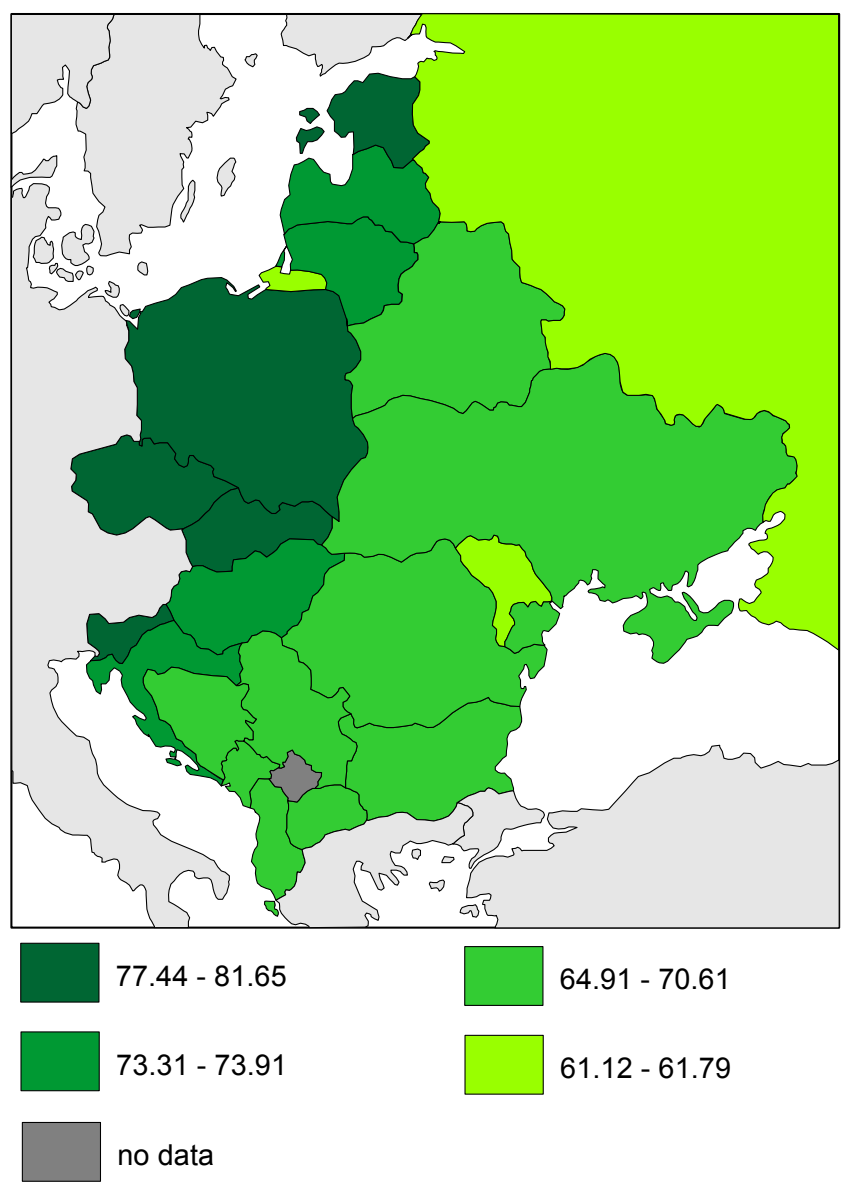

Fig. 2. The values of the Social Progress Index in European post-Communist countries in 2014 (source: http://www.socialprogressimperative.org/)

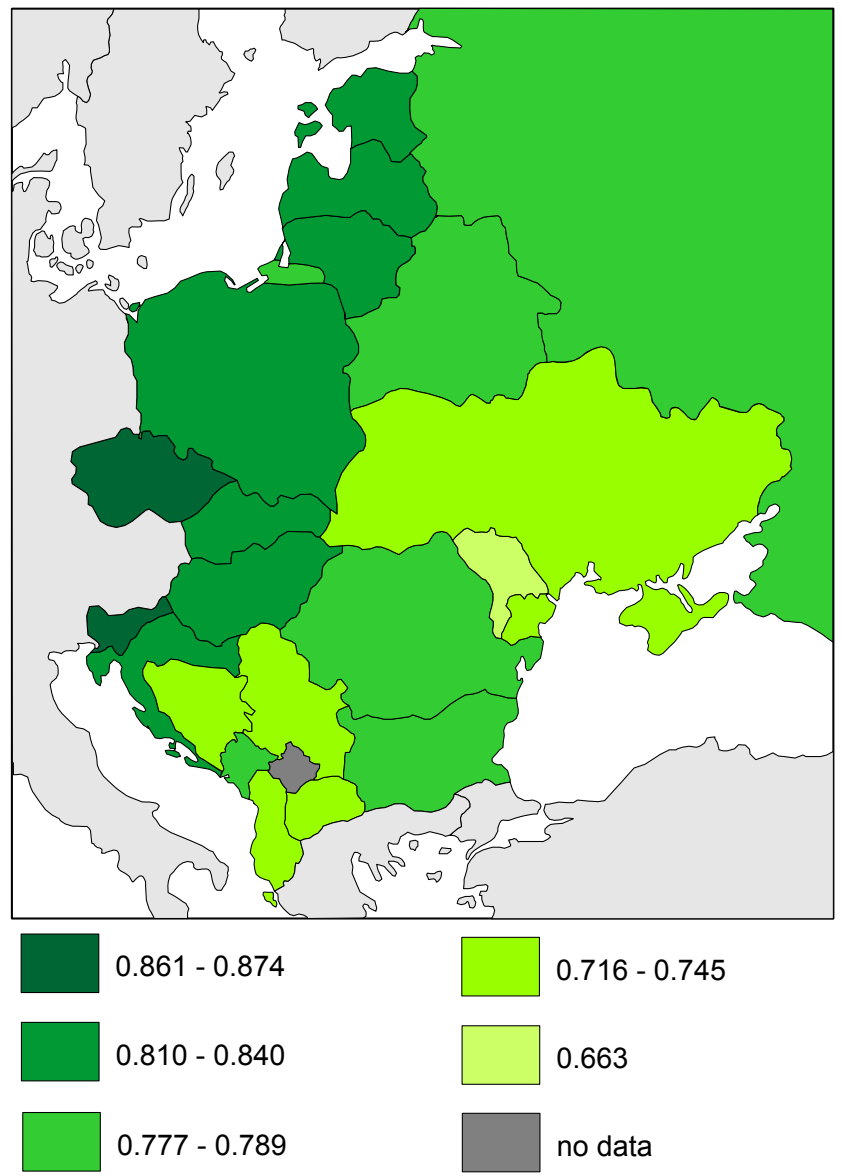

Fig. 3. Human Development Index values in European post-Communist countries in 2013 (source: http://hdr.undp.org/en) 
Figure 4 shows the effects of an attempt to comprehensively depict the overall situation for the populations in the group of countries that were analysed. To this end, a two-stage procedure was applied: (1) first for each of the indicators the ranking was calculated separately in such a way that the best situation was given the rank of 1 , the next one 2, and so on; (2) rankings of all three initial indicators assigned to individual countries were summed.

It was found that Slovenia has the best situation (it took the first place in all three rankings), and Moldova the worst (in two rankings it took last place and in one - the penultimate place) (Kosovo was excluded due to a lack of data). Three groups of countries have been identified (Fig. 4). As predicted, the best situation was reported in the countries which had quickly and effectively initiated the process of transformation. However, the impact of their recent history is not obvious here. There are the states created out of the rubble of Czechoslovakia, Yugoslavia and the Soviet Union and also countries that had been sovereign at the time of the dissolution of the system of socialist states. At the opposite end of the spectrum are countries consumed by internal conflicts and without a clear vision for reform: Moldova, and Bosnia Herzegovina. In-between there is a whole range of countries in various political, social and economic situations - from those clearly aiming at European standards (Bulgaria, Romania and Montenegro) to Belarus and Russia, in which even the reversal of the process of liberal reform has taken place (cf. CIPKO, 2004).

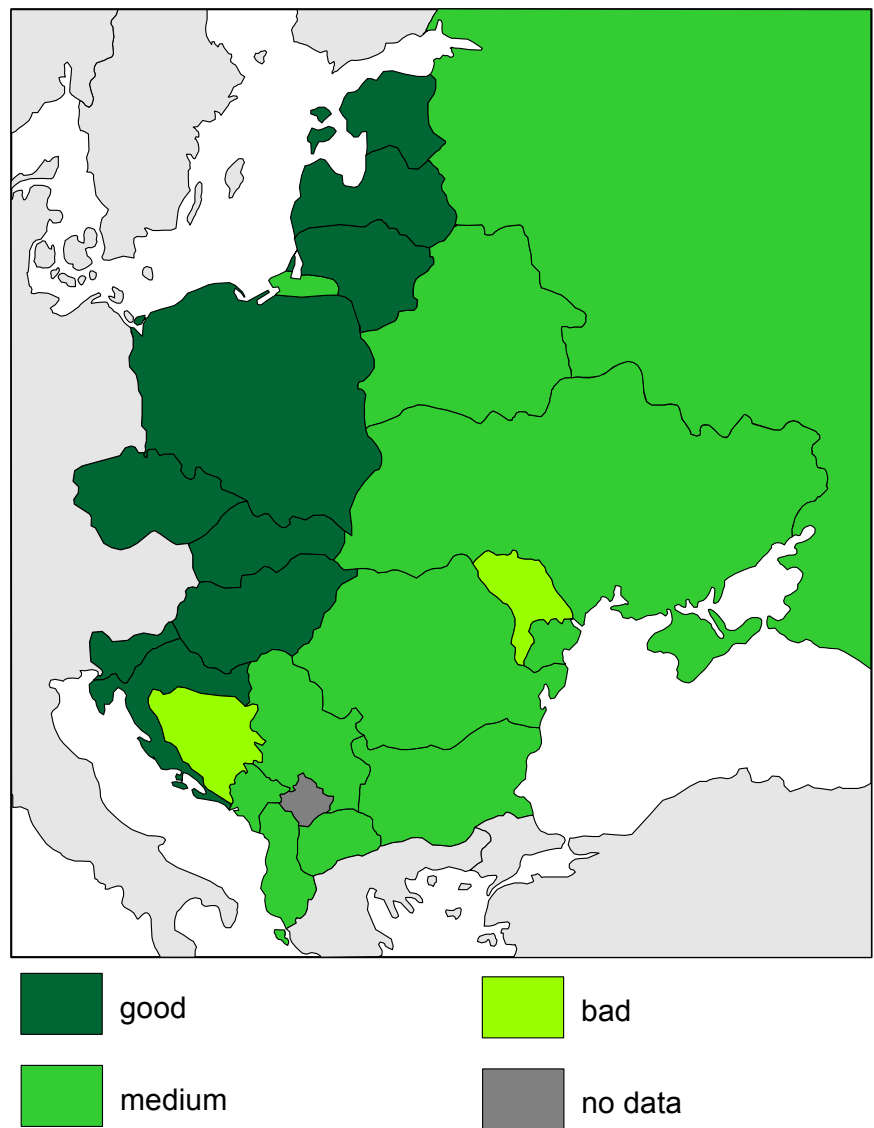

Fig. 4. An overall assessment for the situation of the populations in European post-communist countries in 2013/2014 (source: own elaboration based on distributed materials)

\section{Summary}

One can clearly see that 25 years of transformation following the collapse of the communist system has resulted in a strong diversification in the situation of societies in this part of Europe. In terms of the spatial distributions of the situation which have been described for these populations, one can conclude:
1. A better position exists in the North-West of the analysed group of countries than in the South-East (excluding Russia due to its huge size). This corresponds to the current situation in the EU-15, where the countries situated in the south are in a worse economic and social situation than those located in the north.

2. Typically, the former colonial empires have a higher standard of living than their former colonies. Russia is one of the few exceptions to 
this rule, because more than half of its former colonies $^{7}$ demonstrate a better situation for the population than in Russia itself. One can clearly see that the Russian political elites cannot pull themselves together in the new post-Soviet reality, and it is society that suffers from this ${ }^{8}$.

3. Countries of the Baltic Assembly, especially Estonia, have succeeded the most. These countries, despite a very difficult situation at the beginning of the transition period (resulting from their post-Soviet legacy) are now characterised by a relatively good situation for the population.

4. In those countries that are now members of the EU, it is clear that Bulgaria and Romania have a worse situation for their populations than the other post-communist members of this organization. To a large extent, this is due to negligence in the implementation of reforms at the start of transition (ANDREEV, 2009; Floresu-Ciobotaru, 2006; IliEVA, 2012).

About 25 years ago a road to freedom opened for people living behind "the iron curtain". The weakness of the Communist authorities in Moscow allowed both the countries of the so-called "far abroad" and "near abroad" to take action for the benefit of independence or de facto sovereignty. Social attitudes, whose emanation can be seen in the attitude of political elites, were a fundamental factor influencing the success of reforms and, consequently, improvement in the standard of living of these populations. This is very obvious in the case of Estonia (PANAGIOTOU, 2001), which has enjoyed the greatest success in this study.

The present authorities in Moscow not only increasingly seek to limit the libertarian efforts of other nations, but also exert an increasing level of control over its own society. One cannot be quite sure what to expect in the coming years. A lot of will depend on the economic situation in Russia itself (which is rather uncertain due to the country's dependence on the export of raw materials, especially oil and natural gas, see

\footnotetext{
7 What is meant here are countries which until the dissolution of the USSR were under the direct control of Moscow (the so-called near abroad) as well as those keeping a semblance of independence (the so-called far abroad). The very concept of the near abroad and the far abroad is used by Russian ideologues, politicians and some journalists to identify countries that are considered by them as belonging to "the Russian sphere of influence."

8 The analysis was completed for 2014 (in the case of GDP PPP for 2013). Taking into account the current political, social and economic situation in Russia, one should believe that this conclusion is even more to the point.
}

AleKPEROV, 2011) and the political situation in the Ukraine (cf. KUCZABSKI, MiCHALSKI, 2014).

\section{References}

Alekperov V. 2011. Oil of Russia: past, present, and future. East View Press, Minneapolis.

Andreev S.A. 2009. The unbearable lightness of membership: Bulgaria and Romania after the 2007 EU accession. Communist and Post-Communist Stud., 42(3): 375-393.

Bąk M. 2006. Europa Środkowa i Wschodnia wobec wyzwania transformacyjnego. Wyd. Uniw. Gdańskiego, Gdańsk.

Cipko A. 2004. Razmyšlenijâ o prirode i pričinah kraha postsovietskogo liberalizma. Westnik Analitiki, 3(17):4-24.

Czerwiński M. 2005. Białoruś. [in:] Barański M. (ed.) Systemy polityczne państw Europy Środkowej i Wschodniej. Ustrój, organy władzy, partie polityczne. Wyd. Uniw. Śląskiego, Katowice: $17-47$.

Floresu-Ciobotaru M. 2006. Analiză comparativă a reformie propietății în țările Europei Centrale și de Est (Bulgaria, Cesia, Polonia, România, Slovacia, Angaria). Jurnalul Economic, IV(20): 45-59.

Gregor A.J. 1998. Fascism and the New Russian Nationalism. Communist and Post-Communist Stud., 31(1): 1-15.

Hellwig Z. 1968. Zastosowanie metody taksonomicznej do typologicznego podziału krajów ze względu na poziom ich rozwoju oraz zasoby i strukturę wykwalifikowanych kadr. Przegl. Statyst., XV(4): 307-327.

Holmes L. 2009. Crime, organized crime and corruption in post-communist Europe and the CIS. Communist and Post-Communist Stud., 42(2): 265-287.

Ilieva M., 2012. Socialno-ikonomičeskata transformaciâ w B"lgariâ. Osobiennosti i teritorialni pazličiâ. TerArt, Sofiâ.

Ilieva M., Michalski T. 2001. Sytuacja gospodarcza Bułgarii na tle sytuacji w Europie Środkowo-Wschodniej. Pieniądze $i$ Więź, 1(14): 100-107.

Ingram A. 2001. Broadening Russia's borders? The nationalist challenge of the Congress of Russian Communities. Polit. Geogr., 20: 197-219.

Jaskiernia J. 2002. Systemy rządu w państwach Europy Środkowej i Wschodniej. [in:] Complak K. (ed.) Europa Wschodnia - Ameryka Łacińska. Pozycja jednostki i system rządu. Wyd. Uniw. Wrocławskiego, Wrocław: 285-303.

Jilge W. 2014. Analyse: Die Ukraine aus Sicht der "Russkij Mir". Bundeszentrale für politische Bildung: http://www.bpb.de/internationales/europa/russland/1 86517/analyse-die-ukraine-aus-sicht-der-russkij-mir.

Karklins R. 2009. Wszystkiemu winien jest system. Korupcja $w$ krajach postkomunistycznych. Wyd. Sic!, Warszawa.

Kołodko G.W. 2001. Globalization and catching-up: from recession to growth in transition economies. Communist and Post-Communist Stud., 34(3): 279-322.

Kołodko G.W., Gotz-Kozierkiewicz D., Skrzeszewska-Paczek E. 1991. Hiperinflacja i stabilizacja gospodarcza $w$ gospodarce postsocjalistycznej. Polskie Wyd. Ekon., Warszawa.

Kučabs'kij O.G. 2009. Samowrâduwannâ âk resurs suspìl'noï pìdtrimki admìnìstratiwno-teritorìal'noï reformi w Ukraïnì. Efektiwnìst' deržawnogo Uprawlìnnâ DRÌDU NADU, 16/17: 253-263.

Kuczabski A., Michalski T. 2014. Ukrainian post-communist transformation: causes, consequences and threats. Quaestiones Geogr., 33(2): 171-180.

Łatkowski K.I. 2001. Współczesne rosyjskie nurty nacjonalistyczne. [in:] Helanrski S. (ed.) Nacjonalizm. Konflikty narodowościowe w Europie Środkowej i Wschodniej. Wyd. Adam Marszałek, Toruń: 180-187.

Lesečko M.D., Čemeris A.O. 2001. Admìnìstratiwna reforma: 
doswìd Pol'ŝì ta ukraïns'kì realìi. Aktual'nì Problemi Deržawnogo Uprawlìnnâ OF UADU, 4: 91-105.

Moskwa D. 2013. W poszukiwaniu tożsamości narodowej «Russkij» czy «Rossijskij Narod»? Naukowì zapiski Hacìnal'nogo unìwersitetu «Ostrowz'ka akademiâ» Serîâ «Kul'turologiầ, 12: 63-78.

Panagiotou R.A. 2001, Estonia's success: prescription or legacy? Communist and Post-Communist Stud., 34(3): 261-277.

Rutland P. 2014. Still out in the cold? Russian's place in a globalizing world. Communist and Post-Communist Stud., 45(3-4): 343-354.

Słobodzian L. 2010. Mała i duża prywatyzacja w Rosji w okresie transformacji. Studia i Prace Kolegium Zarządzania i Finansów SGH, 97: 34-47.

Sobczyński M. 2002. The ex-military areas as an element of contemporary spatial structure of Central-Eastern Europe. [in:] Kitowski J. (ed.) New arrangements of socio-economic links in Central and Eastern Europe. Wyd. Oświatowe FOSZE, Rzeszów: 91-109.

Sobczyński M. 2010. Geopolitical transformation in Central and Eastern Europe at the turn of the $20^{\text {th }}$ and $21^{\text {st }}$ centuries. [in:] Kitowski J. (ed.) 20 years of socio-economic transformation in countries of Central and Eastern Europe - an attempt of accounts. Ser. Geopolit. Stud., 16, IGiPZ PAN Warszawa: 5-45.

Sobczyński M. 2013. Zmiany polityczne, terytorialne i spory graniczne w Europie Środkowo-Wschodniej po 1989 r. [in:] Eberhardt P. (ed.) Studia nad geopolitykq XX wieku. Ser. Prace Geogr. IGiPZ PAN, Nr 242, IGiPZ PAN, Warszawa: 181-233.

Stryjakiewicz T. 2004. Sieci gospodarcze w Polsce w warunkach transformacji systemowej. [in:] Parysek J.J. (ed.) Rozwój regionalny $i$ lokalny $w$ Polsce $w$ latach 1989-2002. Bogucki Wyd. Nauk., Poznań: 25-44.

Sztompka P. 2000. Trauma wielkiej zmiany. IPN PAN, Warszawa. Tischner J. 2005. Etyka solidarności oraz Homo Sovieticus. Wyd. Znak, Warszawa.

Wendt J. 2007. Wymiar przestrzenny struktur i aktywności społeczeństwa obywatelskiego w Polsce. Series: Prace Geogr., IGiPZ PAN, Nr 208, IGiPZ PAN, Warszawa.

Wìnnìkow O., Morozowa G. 1998. Pitannâ ekonomì̌nogo rozbitku samowrâdnih gromad w Ukraïnì. Aspekti Samowrâduwannâ, 2: 2-5.

Zinoviev A. 1986. Homo Sovieticus. Atlantic Monthly Press, Boston.

http://en.rsf.org/

http://hdr.undp.org/en

http://hdr.undp.org/en

http://russkiymir.ru/

http://www.heritage.org/

http://www.prosperity.com/\#!/

http://www.socialprogressimperative.org/

http://www.transparency.org/ 